\title{
INVESTIGATION OF EBT3 RADIOCHROMIC FILM RESPONSE IN A HIGH-DOSE RANGE OF 6 MV PHOTON AND 6 MEV ELECTRON BEAMS USING A THREE-COLOR FLATBED SCANNER
}

\author{
Kerem Duruera,*, Durmuş Etiz ${ }^{a}$, (D) Haluk Yücel ${ }^{b}$ \\ ${ }^{a}$ Eskişehir Osmangazi University Faculty of Medicine Department of Radiation Oncology \\ 26010 Odunpazarl, Eskişehir, Turkey \\ ${ }^{b}$ Ankara University Institute of Nuclear Sciences \\ 06500 Beşevler, Ankara, Turkey \\ *Corresponding Author: kduruer@ogu.edu.tr \\ Received April 7, 2020; revised April 15, 2020; accepted April 23, 2020
}

Radiochromic film dosimetry has been commonly used for determination of dose measurement in radiotherapy for many years because of their high spatial resolution, low energy dependence and its approximate tissue equivalent. Additionally, it has other practical advantages, e.g.it is suitable for therapy range beam qualities, a water resistance material, a relatively insensitive to visible light, and does not need to make bathing process to obtain dose information. They are also independent to dose rate. Hence, they are very useful and practical for clinical applications such as brachytherapy, electron therapy, skin dose measurements and stereotactic radiotherapy. Among them, the dynamic dose range of EBT3 radiochromic films are generally recommended for the dose range of 0.1 to 20 Gy. However, in this study, it is aimed to observe the behavior of EBT3 films in high dose range of up to 90 Gy under the irradiations. For this aim, the net optical densities were obtained with increasing dose values under photon and electron beams by employing three color scanning channels (red-green-blue). Thus, for making calibration curves, it was decided which color channel for EBT3 radiochromic film would be the most suitable one in different dose ranges. In experimental setup, the reference circumstances were first established and dose calibration procedure was carried out in RW3 phantom. Then the irradiated films were cut carefully into $2 \times 2.5 \mathrm{~cm}^{2}$ pieces, and they were grouped into 2 as irradiation and control groups. The control group was waited for background, i.e. they are not irradiated. Before the irradiation, two groups of films have been scanned in flatbed scanner for three channels. After that, the irradiation group films were placed to align the exact place of effective point of ionization chamber under the reference condition. Later, they were irradiated one by one to up to $90 \mathrm{~Gy}$ with using $6 \mathrm{MV}$ and $6 \mathrm{MeV}$ beam qualities, respectively. Subsequently, both of film groups were again scanned in flatbed scanner for three - color channels. Optical densities and their standard deviations corresponding to the chosen dose values were obtained from the scanned films. Thus, calibration curves were plotted for all three colors channel according to two different beam conditions. The results obtained for $6 \mathrm{MV}$ beam quality showed that if red color channel is selected for $0.9 \mathrm{~Gy}-7.3 \mathrm{~Gy}$ dose range, and green color channel is selected for $7.3 \mathrm{~Gy}-42.8 \mathrm{~Gy}$ dose range, and blue color channel is selected for $42.8 \mathrm{~Gy}-90.0 \mathrm{~Gy}$ dose range, the percentage uncertainty values in the obtained results are minimal. For the $6 \mathrm{MeV}$ beam quality, if red color channel is selected for 0.9 Gy-7.7 Gy dose range, and green color channel is selected for 7.7 Gy-45.3 Gy dose range, and blue color channel is selected for 45.3 Gy-90.0 Gy dose range, the percentage uncertainty values in the obtained results are minimal. In conclusion, the percentage uncertainty values for the obtained results were evaluated for $6 \mathrm{MV}$ photon and $6 \mathrm{MeV}$ electron energies by using different scanning channels of EBT3 radiochromic film. It has been found that measurements having low percentage uncertainty values can be achieved by changing the scanning channel by deciding proper combinations with increasing doses for both energies (6MV photon and $6 \mathrm{MeV}$ electron). The study also shows that EBT3 radiochromic films can be used at lower percentage uncertainty values at doses higher than the recommended dose range values.

KEYWORDS: Radiochromic Film, Uncertainty, High Dose Range, Radiotherapy, Flatbed Scanner

Radiochromic films are very useful two-dimensional (2D) dosimetric systems well known for many advantages, such as high spatial resolution [1-5], low energy dependence at a wide energy range of energies greater than $100 \mathrm{keV} \mathrm{[6],}$ approximating tissue equivalence at radiotherapy energies [6], water resistance $[4,7,8]$, relative insensitivity to visible light, which allows the processing and handling of the film in room light $[4,9,10]$, minimal self-spontaneous darkening after film irradiation, thus eliminating the need for any post-irradiation bathing procedure to reveal darkening in contrast to conventional radiography films. Compared with other 2D dosimetric systems, radiochromic films, with their specific suitable properties [2,11], are considered to be highly effective 2D detectors [5]. They provide a highly detailed dose map in a 2D plane and can also be used for a three-dimensional (3D) volumetric analysis when curled or coiled [9]. For almost 30 years (by the mid 1980's) [1], these films have been used for both clinical and research purposes, including brachytherapy, electron therapy, total skin electron therapy, skin dose measurements, whole-body irradiation, stereotactic radiotherapy, dosimetric characterization of proton therapy, and dose verification during cell irradiation in radiobiological experiments [2,3].

Following the launch in 2004 of the EBT GAFChromic film in the medical market, EBT2 GAFChromic film was introduced in 2008. It has the same sensitive layer as in the first version, but the non-homogeneity of the sensitive layer was corrected through the addition of a yellow marker dye. In 2011, the EBT3 GAFChromic film entered the medical market, and this improved version eliminates the artifacts produced by the EBT2 film, such as Newton's rings [5].

Light intensity measurements are conducted to determine the radiochromic film response using transmission, reflection, or both depending on the scanner type and function. Since radiochromic films generally have a wide optical absorption spectrum, the frequency or bandwidth of the light source to be used in the scanner must be specified in (C) K. Duruer, D. Etiz, H. Yücel, 2020 
advance [10]. Two main absorption bands lying in $636 \pm 3 \mathrm{~nm}$ and $585 \pm 2 \mathrm{~nm}$ have been shown in the optical absorption spectra of EBT, EBT2 and EBT3 radiochromic films, some researchers suggested the presence of a third absorption band with a lower center lying in $560 \pm 6 \mathrm{~nm}$ [8]. For EBT3 radiochromic films, the manufacturer recommends the use of the red channel for irradiation up to $8 \mathrm{~Gy}$ and the green channel for irradiation at doses from 8 to $40 \mathrm{~Gy}[12,13]$.

In this study, the commercially available EBT3 GAFChromic ${ }^{\mathrm{TM}}$ (Ashland Specialty Ingredients, Bridgewater, NJ, USA) was selected as a radiochromic film frequently examined by other researchers [1,2,4,5,13-15]. The manufacturer of this radiochromic film recommends the use of a dose range of 0.01-30 Gy [2]. However, with the use of high doses in radiotherapy (e.g. stereotactic radiosurgery (SRS) and stereotactic body radiation therapy (SBRT)) [16], the use of radiochromic films in these high doses is increasing. It should also be noted that there are few research findings for a higher dose range; for example, from $40 \mathrm{~Gy}$ up to $90 \mathrm{~Gy}[3,17]$ for radiochromic film irradiations. Thus, the aim of this study was to investigate the response behavior of EBT3 radiochromic films for $6 \mathrm{MV}$ photon and $6 \mathrm{MeV}$ electron beams. For an accurate calibration of the films, the present study covered the dose range recommended by the manufacturer and further higher doses outside this range ( $90 \mathrm{~Gy}$ ) for three different scanning channels (red, green, and blue) in a flatbed scanner. For $6 \mathrm{MV}$ photon and $6 \mathrm{MeV}$ electron beams, it is important to determine the optimal scanning channel for a wide dose range by scanning the RGB channels. To do this, the percentage uncertainty values will be calculated from these calibration curves for the comparison and decision for proper scanning channel. This study also aimed at investigating the ideal scanning time for the EBT3 films for different scanning channels in terms of polymerization [2], which continues after irradiation and actually never stops.

\section{MATERIAL AND METHOD}

Radiochromic films can be used as reference dosimetric systems and are therefore utilized in absolute dose measurements, as well as in other dosimetric systems (e.g., ion chambers) [2]. The main principle of dose measurements by reference dosimetric systems using films is that they are based on the calibration curve obtained under reference conditions. Thus, the reference dose values must be measured under reference conditions prior to the calibration process. For this purpose, in this study, the TRS 398 protocol [18] was selected as reference measurement conditions.

\section{Calibration of radiochromic film (dosimeter)}

The calibration process of the radiochromic films was carried out at $6 \mathrm{MV}$ photon and $6 \mathrm{MeV}$ electron beam qualities using the Elekta Precise model linear accelerator (Elekta AB, Stockholm, Sweden) at the Radiation Oncology Department of Eskişehir Osmangazi University Medical Faculty Hospital. In the calibration process, first, the output (dose) values were measured and calibrated [18]. For this purpose, the experimental setup was established by using $30 \times 30 \mathrm{~cm}^{2}$ waterequivalent solid phantoms (RW3 Slab Phantom, PTW-Freiburg, Freiburg, Germany). A 0.6 cc PTW Farmer cylindrical ion chamber (PTW-Freiburg, Freiburg, Germany) was utilized for the $6 \mathrm{MV}$ photon beam quality and a $0.02 \mathrm{cc}$ PTW Marcus-type parallel plate ion chamber (PTW-Freiburg, Freiburg, Germany) for the $6 \mathrm{MeV}$ electron beam quality. These ion chambers were calibrated at SSDL (Secondary Standard Laboratory) of the Turkish Atomic Energy Authority. To ensure that the measurements were performed under reference conditions, the effective point of the ion chamber was placed at a depth of $10 \mathrm{~cm}$ for the $6 \mathrm{MV}$ photon beam quality and the $\mathrm{d}_{\max }$ depth (measured with water phantom measurement and the measurement result was $1.2 \mathrm{~cm}$ ) for the $6 \mathrm{MeV}$ electron beam. A $20 \mathrm{~cm}$ solid phantom was placed under the ion chambers at all energies to capture backscatter radiation. With the gantry set to $0^{0}$ angle, the source detector distance was adjusted to $100 \mathrm{~cm}$ and the field size to $10 \times 10 \mathrm{~cm}^{2}$. Before the irradiation process, the electrometer was turned on and allowed to warm up for approximately 20 minutes without any irradiation. Irradiations were performed at $10,20,30,50,100,200,400$ and $1000 \mathrm{MU}$, respectively, and these measurements were repeated three times, in which one monitor unit (MU) equals approximately to the $0.01 \mathrm{~Gy}$ absorbed dose value.

In this study, at the times when the films were not being irradiated or scanned, they were always stored in dark in a temperature-controlled environment at room temperature. The available EBT3 films from lot number 05171701 was used and they had not expired. The films were handled in accordance with the protocol AAPM Task Group55 [19]. While handling with the films, gloves were always worn to prevent artifact formation on their surfaces during all procedures, such as cutting and placing the films in the scanner. Clean sharp scissors were used to cut the films in order to minimize damage to their layers [10].

The sensitive layer in the radiochromic film changes color when exposed to radiation due to polymerization. The absorption of the measurement light by the film results in the film itself acting as a polarizer. Thus, rotating the film in the scanner would produce different results even in the same region of interest (ROI) ${ }^{(2)}$. In addition, reverse-reading of the irradiation side, which is a problem encountered in the previous-generation EBT2 film (the active layer of EBT2 radiochromic films is not completely centered [2]), is not seen in new-generation EBT3 radiochromic films due to the sensitive layer being located right in the center, allowing for the separation of the irradiation and reading surfaces.

According to the calibration procedure described by Devic et al. [2], the films for which the calibration curves are to be obtained are divided into two groups: those to be irradiated and the non-irradiated control films that are used to eliminate the effect of natural radiation caused by light and radiation in the environment on the measurements. These two batches of films were scanned both before and after the irradiation process. Before scanning, empty scans were performed after waiting for $15 \mathrm{~min}$ to warm up the scanner. 
The films were cut into rectangles of $2.0 \times 2.5 \mathrm{~cm}^{2}$ pieces and placed in the scanner in the same direction. After radiochromic films are irradiated by ionizing radiation, the color components are separated when the films are digitized with white light. When radiochromic films were used, multi-channel scanners would offer good results due to their high sensitivity resulting from their high selectivity to the red channel in the low-dose region and similar sensitivity in highdose areas for the green and blue channels [15]. In flatbed scanners, the most optimal scanning mode is RGB, resulting in less noise and higher sensitivity; therefore, we chose the 48-bit mode; i.e., 16-bit depth for each color [2]. The scanner used in the research was a multi-channel Epson Expression 11000XL Flatbed scanner (Epson Seiko Corporation, Nagano, Japan).

The films to be irradiated and the control films were placed flat in order to eliminate any rotational effect and at the center of the scanner in the same direction to eliminate any lateral scattering effect [5]. Scanning was performed twice at $72 \mathrm{dPi}$ (dots per inch) scan resolution in the transmission mode and horizontal orientation. Four films were scanned at a time (lateral scanning length of about $10 \mathrm{~cm}$ ). The results obtained were evaluated by taking the average of the two scans.

During the scanning process, a signal may be generated in the detector even if there is no transmission, which is due to the thermal noise caused by the Charge Coupled Device (CCD) detector [2]. In order to prevent this signal from affecting the measurement results, pieces of thin black cardboard thick enough were used to prevent the passage of scanning light, and these results were recorded as 'background signal' and subtracted from the pixel values of the irradiated and control group films during the calculation.

After performing the pre-irradiation scanning process, the EBT3 radiochromic films were irradiated by dosecalibrated $6 \mathrm{MV}$ photon and $6 \mathrm{MeV}$ electron beam qualities with 0-90 Gy dose range. The small pieces of the films were irradiated one by one under the same geometrical and dosimetric conditions described as the reference conditions, as shown in Figure 1, in which the films are placed in a water-equivalent solid phantom at a depth corresponding to the effective point of an ion chamber. In addition, considering that polymerization continues after irradiation, in order to determine the changes in polymer behavior over time for different scanning channels, one film was irradiated up to 10 Gy at the $6 \mathrm{MV}$ photon energy and scanned immediately after irradiation while the others were scanned at post-irradiation hours $0,1,2,3.5,4.5,5.5,6.5,7.5,8.5,12,24,48$ and 120 . The obtained results were evaluated separately for each channel in terms of the variation in optical density by scanning time. In this procedure, the scanning performed immediately after irradiation was adopted as "reference scanning" for all three channels to evaluate the \% differences in other scan times in term of optical density. Here, it should be noted that in accordance with the result obtained from this part of the study, all the remaining scans were carried out approximately 48 hours after irradiation to minimize the effect of radiation-induced continuous polymer behavior $[2,10,16,20,21]$.

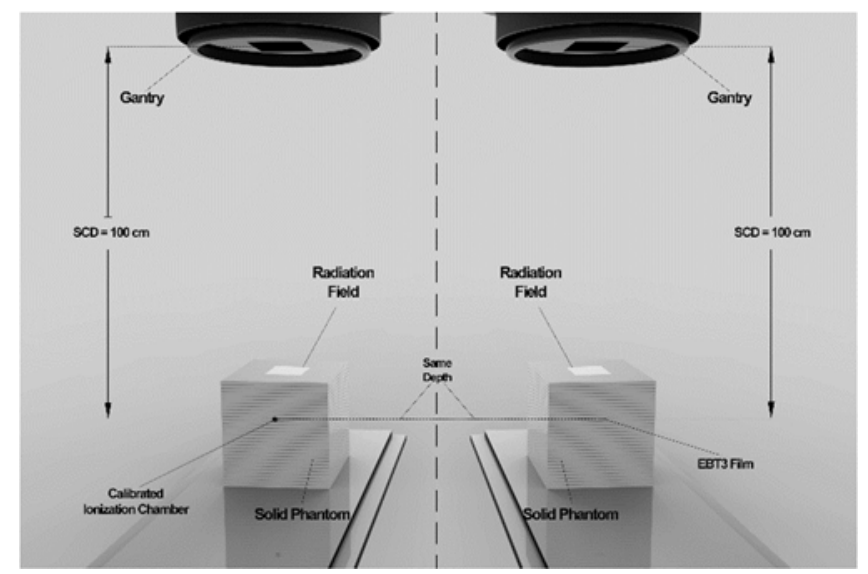

Figure 1. Experimental setup of beam and radiochromic film calibration

The images of the films that were scanned were saved in the "**tiff "(tagged image file format) format and opened in Image J image-processing software (National Institutes of Health, 1997). Since the beams used in the calibration process are assumed to be homogeneous and most radiochromic films and 2D detector systems slightly deviate from homogeneity by nature; therefore, five ROIs were determined and their pixel values were then combined in weighted averages. The weighted average values were evaluated to achieve more homogeneous results in these measurements. The images of each film were measured individually for the RGB channels. The measurement results were calculated separately using Equations which are described by Devic et al. [2]. The optical density and its standard deviation were determined for each energy, as well as for the three different channels.

\section{RESULTS AND DISCUSSION}

Figure 2 shows the percentage change of optical density in the films for the RGB channels with the increasing reading time (i.e., time of scanning). This indicates that the optical densities in the RGB channels were strongly related to the time of scanning when we changed it from 0 to 120 hours under reference irradiation conditions. A remarkable 
increase in optical density was observed with the delay in scanning time for all three channels, and after a certain period, the percentage of increase began to gradually decrease. The percentage difference at hour 120 was $6.02 \%$ for the red channel, $7.72 \%$ for green, and $15.97 \%$ for blue. For all three channels, the increase after hour 24 was reduced compared to the increase within the first 24 hours, and the difference between hours 24 and 48 hours was $0.71 \%$ for the red channel, $1.24 \%$ for green, and $1.72 \%$ for blue. The differences in optical density between hours 48 and 120 were $0.83 \%, 0.56 \%$ and $0.26 \%$ for the red, green and blue channels, respectively. In particular, there was a remarkable increase in optical density for all three channels within the first 12 hours. Although the results of the 12th hour significantly differed from that of the 24th-hour reading, which is a widely used protocol [2], the results mentioned above support the idea that performing reading after 48 hours of radiation exposure provides more accuracy in the evaluation of the measurement results when EBT3 films are used.

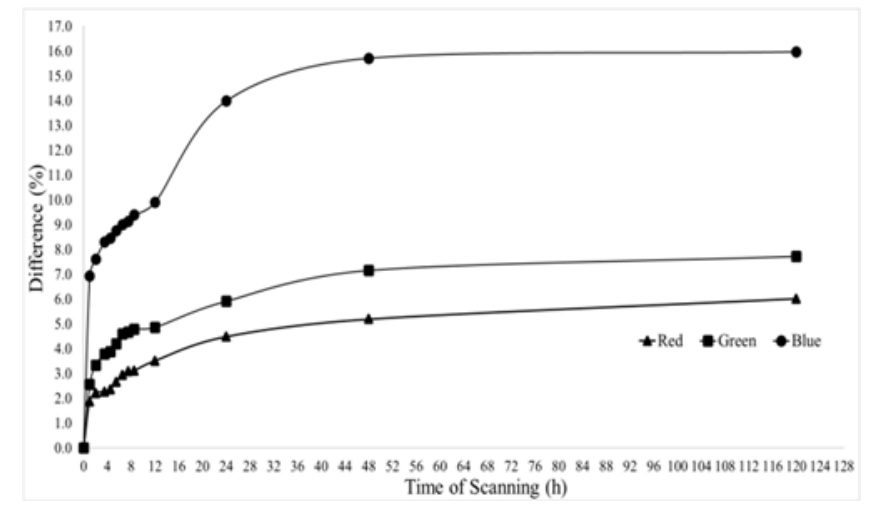

Figure 2. Percentage Difference of Optical Density of EBT3 Radiochromic Film in different scanning channels when post-irradiation time was selected as reference time

Considering that the differences that occurred within 72 hours from hour 48 to hour 120 was very low for all three channels while the 24-hour differences from hours 24 to 48 were greater compared to the 72-hour differences and that polymerization never stops. From these findings, the optimum scanning time for the EBT3 radiochromic film was determined as 48 hours. In the literature, Borca et al. [17] irradiated EBT3 radiochromic films at different doses from $0.3 \mathrm{~Gy}$ to $4 \mathrm{~Gy}$ and compared the scan results (in terms of optical density) obtained at different hours from 30 minutes to 6 hours with the 24-hour measurement results. The authors calculated the difference in optical density between the secondand 24th- hour scan results to be less than $2.5 \%$, which was similar $2.48 \%$ for the red channel at $10 \mathrm{~Gy}$ in our study. In addition, among the three channels, the highest percentage deviation from the reference optical density values obtained immediately after irradiation was observed in the blue channel and the lowest in the red channel. The \% difference in optical density for hour 24 was $4.48 \%$ for the red channel, $5.91 \%$ for the green channel, and $13.99 \%$ for the blue channel. From this perspective, if the blue channel is to be used, it is important to wait for 48 hours before reading in order to achieve measurement results with lower uncertainties.
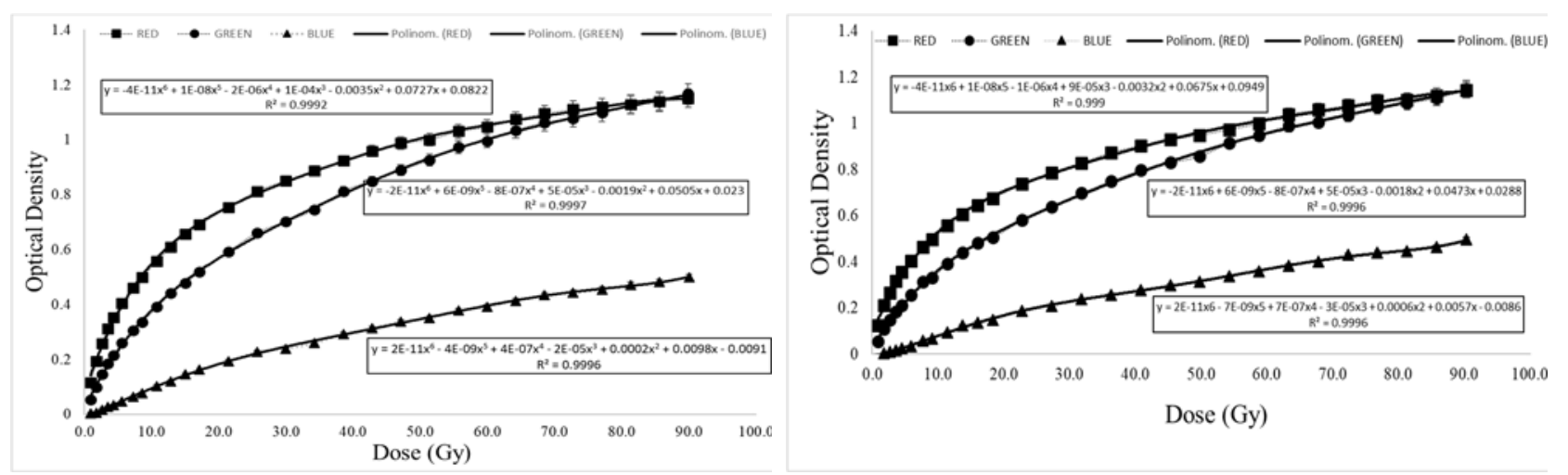

Figure 3. The calibration curves of EBT3 radiochromic film for the three channels at $6 \mathrm{MV}$ photon beam quality

Figure 4. The calibration curves of EBT3 radiochromic film for the three channels at $6 \mathrm{MeV}$ electron beam quality

The calibration curves are shown in Figures 3 and 4 with polynomial fit function for the EBT3 radiochromic film for the three channels at $6 \mathrm{MV}$ photon and $6 \mathrm{MeV}$ electron beam qualities, respectively. The results obtained for the $6 \mathrm{MV}$ photon and $6 \mathrm{MeV}$ electron beam qualities revealed similar trends in the reading values. The curves obtained for the red and green channels showed an increasing tendency in optical density with a greater slope in the low- and medium-dose 
regions (up to $20 \mathrm{~Gy}$ ) while the slope of this increase began to decrease after about $20 \mathrm{~Gy}$, with a considerable decrease seen in the range of about 40-50 Gy. For the blue channel, there was a continuous increase with a lower slope across all dose regions. This behavior of the three channels is consistent with the reported results in the literature [3,17]. We observed that the considerable decrease in the slope after about 40-50 Gy for the red and green channels, but not for the blue channel can be explained by the absorption spectrum of the EBT3 radiochromic film. In these films, the absorption rate is higher for the red and green channels than in the blue channel, in which saturation is only observed after 40-50 Gy, this result explains why there was a remarkable decrease in the rate of increase in optical density in this dose region [3].

The $\%$ uncertainty being low in the low-dose region (0-8 Gy) for the red channel, medium-dose region (8-40 Gy) for the green channel, and high-dose region ( $>40 \mathrm{~Gy}$ ) for the blue channel at both beam qualities can be explained by the behavior of the EBT3 radiochromic film toward these three colors in the absorption spectrum. Marroquín [8] investigated the absorption spectrum of the EBT3 radiochromic film and observed that the highest absorption occurred in the red region. Therefore, when the low-dose region is examined, the \% uncertainty value in the red channel with the highest absorption is expected to be low. Accordingly, in the high-dose region, the uncertainty in the blue channel with an absorption rate lower than the other two-color channels (red-green) would be lower due to not having yet reached saturation. The uncertainty percentages obtained in this study for two different beam qualities were similar to those reported by Marroquín [3] for the $6 \mathrm{MV}$ photon energy up to $120 \mathrm{~Gy}$. Figures 5 and 6 show the $\%$ uncertainty values for three channels and Figures 7 and 8 show the most optimal scanning channels for the $6 \mathrm{MV}$ photon and $6 \mathrm{MeV}$ electron beam qualities, which should be used in terms of \% uncertainty in a dose region of approximately $90 \mathrm{~Gy}$. According to the graph obtained for the $6 \mathrm{MV}$ photon beam quality, the \% uncertainty would be lower for the values acquired using the red channel at doses up to $7.3 \mathrm{~Gy}$, green channel at $7.3 \mathrm{~Gy}$ to $42.8 \mathrm{~Gy}$, and blue channel at $42.8 \mathrm{~Gy}$ to $90.0 \mathrm{~Gy}$, compared to the cases in which these channels are used at different doses. The graph obtained for the $6 \mathrm{MeV}$ electron energy revealed that the uncertainty rate would be lower if the red channel is used at doses up to $7.7 \mathrm{~Gy}$, green channel at 7.7 Gy to $45.3 \mathrm{~Gy}$, and blue channel at $45.3 \mathrm{~Gy}$ to $90.0 \mathrm{~Gy}$. These findings are in agreement with the manufacturer's recommendations and the results reported by Marroquín [3].

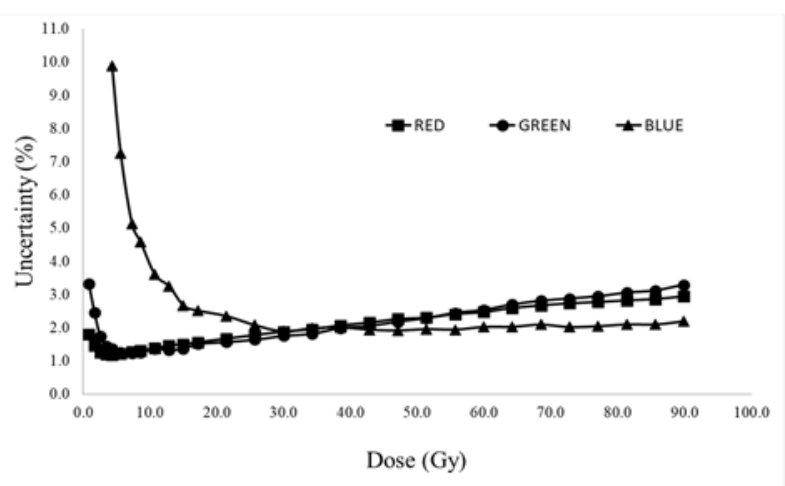

Figure 5. Uncertainty analysis for $6 \mathrm{MV}$ Photon Beam Calibration Curves for all three color channel (It isn't shown in the graph as the uncertainty \% of the values for blue channel below 5 Gy was higher than \%10)

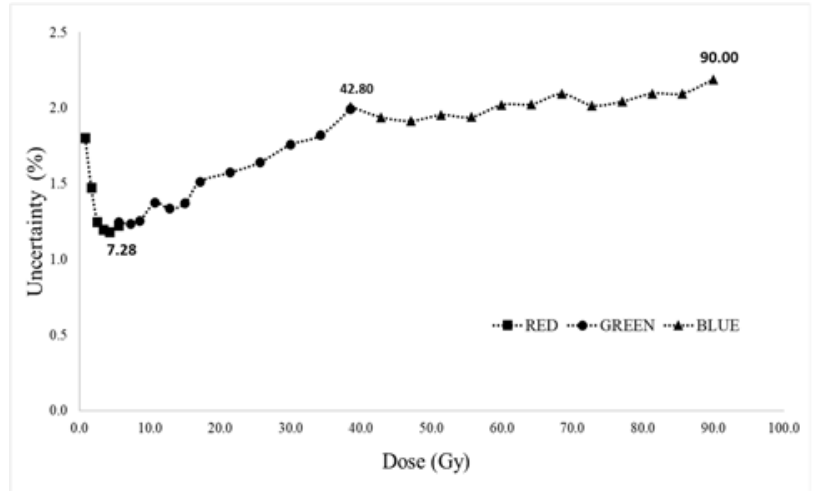

Figure 7. The most optimal scanning channels for the $6 \mathrm{MV}$ photon beam quality, which should be used in terms of $\%$ uncertainty in a dose region of $90 \mathrm{~Gy}$

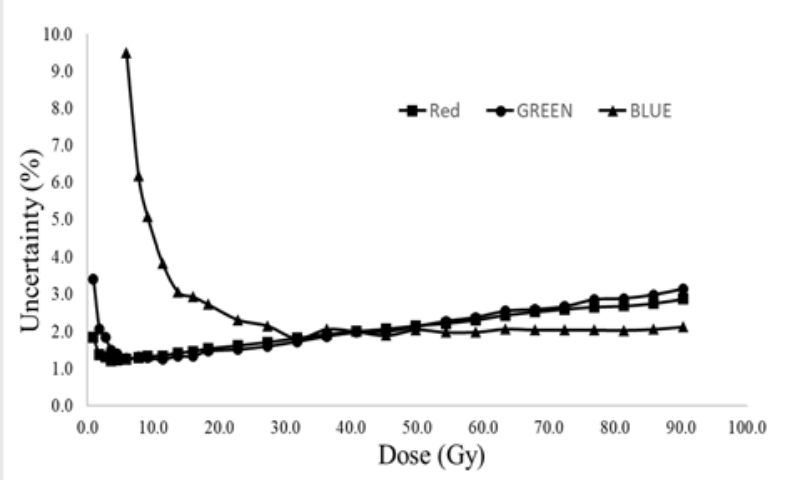

Figure 6. Uncertainty analysis for $6 \mathrm{MeV}$ Electron Beam Calibration Curves for all three color channel (It isn't shown in the graph as the uncertainty $\%$ of the values for blue channel below 6 Gy was higher than \%10)

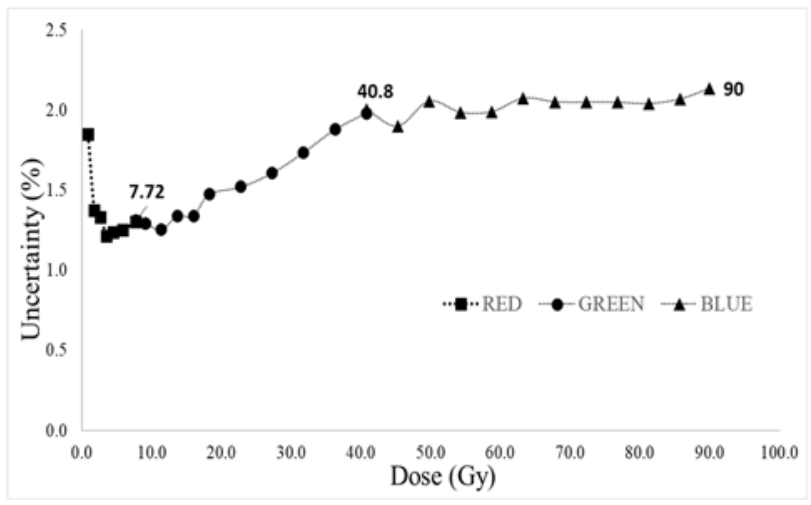

Figure 8. The most optimal scanning channels for the $6 \mathrm{MeV}$ photon beam quality, which should be used in terms of $\%$ uncertainty in a dose region of approximately $90 \mathrm{~Gy}$ 


\section{CONCLUSION}

In this study, the calibration curves of EBT3 radiochromic films were obtained using higher dose values of up to $90 \mathrm{~Gy}$ for the $6 \mathrm{MV}$ photon and $6 \mathrm{MeV}$ electron beam qualities to determine the best scanning channel at different doses in terms of minimum \% uncertainty values for each beam quality. Therefore, this study would be useful for users who will work with EBT3 radiochromic film and multi-channel scanner at doses up to $90 \mathrm{~Gy}$ for the $6 \mathrm{MV}$ photon and $6 \mathrm{MeV}$ electron beam qualities. In addition, when EBT3 radiochromic films are used in a multi-channel scanner at either $6 \mathrm{MV}$ photon or $6 \mathrm{MeV}$ electron beam quality, the scanning channel should be selected as red for the dose ranges of conventional radiotherapy applications (3D CRT and IMRT). However, it is clear that the green channel requires even higher doses, such as in SBRT applications, and the blue channel can be used in any application involving a dose higher than about $40 \mathrm{~Gy}$ in order to achieve lower \% uncertainty values in the measured dose values when using a three-color flatbed scanner.

Also, in the time interval up to 120 hours, the optimal scanning time has been determined in this study. This would be very beneficial for the users in deciding on the optimum scan time when a multi-channel scanner is used because of the polymerization behavior of EBT3 radiochromic films that continues after the irradiation process. The results revealed that for the EBT3 radiochromic film, it would be more appropriate for both higher practicality and accuracy to perform reading at hour 48. In future work, we aim to investigate the response behavior of radiochromic films to beta sources used in brachytherapy using a three-color flatbed scanner.

\section{ACKNOWLEDGMENTS}

This work was supported by TUBİTAK Project No: 118S616. This work is also a part of Ph.D. dissertation study of Mr. Kerem Duruer in Ankara University, Turkey.

\section{ORCID IDs}

Kerem Duruer, https://orcid.org/0000-0003-2303-4070; DDurmuş Etiz, https://orcid.org/0000-0003-0793-4941

Haluk Yücel, https://orcid.org/0000-0002-3084-9596

\section{REFERENCES}

[1] I.J. Das (Ed), Radiochromic Film Role and Applications in Radiation Dosimetry, (CRC Press, Boca Raton, 2017), pp. xiii.

[2] S. Devic, N. Tomic, and D. Lewis, Reference radiochromic film dosimetry: Review of technical aspects, Physica Medica, 32 541-556 (2016), https://doi.org/10.1016/j.ejmp.2016.02.008.

[3] E.Y. León-Marroquín, J.A. Herrera-González, M.A. Camacho-López, J.E. Villarreal-Barajas, and O.A. García-Garduño, Journal of Applied Clinical Medical Physics, 17(5), 466-481 (2016), https://dx.doi.org/10.1120\%2Fjacmp.v17i5.6262.

[4] L. Marrazzo, M. Zani, S. Pallotta, C. Arilli, M. Casati, A. Compagnucci, C. Talamonti, and M. Bucciolini, Physica Medica 31, 1035-1042 (2015), https://dx.doi.org/10.1016/j.ejmp.2015.08.010.

[5] L.J. Van Battum, H. Huizenga, R.M. Verdaasdonk, and S. Heukelom, Phys. Med. Biol. 61, 625-49 (2016), https://doi.org/10.1088/0031-9155/61/2/625.

[6] H. Bekerat, S. Devic, F. DeBlois, K. Singh, A. Sarfehnia, J. Seuntjens, S. Shih, X. Yu, and D. Lewis, Medical Physics, 41(2), 022101 (2014), https://doi.org/10.1118/1.4860157.

[7] M. Butson, and A. Niroomand-Rad, in: Radiochromic Film Role and Applications in Radiation Dosimetry, edited by I.J. Das, (CRC Press, Boca Raton, 2017), pp. 7-28.

[8] E.Y. León-Marroquín, D.J. Mulrow, R. Khan, and A. Darafsheh, Med. Phys. 46(2), 973-982 (2019), https://doi.org/10.1002/mp.13330.

[9] M. Butson, G. Cho, S. Gill, and D. Pope, in: Radiochromic Film Role and Applications in Radiation Dosimetry, edited by I. J. Das, (CRC Press, Boca Raton, 2017), pp. 34-56

[10] S. Devic, Physica Medica, 27, 122-134 (2011), https://doi.org/10.1016/j.ejmp.2010.10.001.

[11] E.Y. León-Marroquín, M.A. Camacho-López, O.A. García-Garduño, J.A. Herrera-González, J.E. Villarreal-Barajas, R. GutiérrezFuentes, and R. Contreras-Bulnes, Radiation Measurements, 89, 82-88 (2016), https://doi.org/10.1016/j.radmeas.2016.03.007.

[12] J.E. Villarreal-Barajas, and R.F.H. Khan, Journal of Applied Clinical Medical Physics, 15(1), $331-338$ (2014), https://doi.org/10.1120/jacmp.v15i1.4439.

[13] S.W. Kang, J.B. Chung, K.H. Kim, K.Y. Eom, C. Song, J.W. Lee, W. Cho, and T.S. Suh, Evaluation of Dual-channel Compound Method for EBT3 Film Dosimetry, Progress in Medical Physics, 28(1), 16-21 (2017), https://doi.org/10.14316/pmp.2017.28.1.16.

[14] S.H. Benedict, K.M. Yenice, D. Followill, J.M. Galvin, W. Hinson, B. Kavanagh, P. Keall, M. Lovelock, S. Meeks, L. Papiez, T. Purdie, R. Sadagopan, M.C. Schell, B. Salter, D.J. Schlesinger, A.S. Shiu, T. Solberg, D.Y. Song, V. Stieber, R. Timmerman, W.A. Tomé, D. Verellen, L. Wang, and F.F. Yin, Medical Physics, 37(8), 4078-101 (2010), https://doi.org/10.1118/1.3438081.

[15] D. Lewis, A. Micke, X.Yu, and M.F. Chan, Medical Physics, 39(10), 6339-50 (2012), https://doi.org/10.1118/1.4754797.

[16] T. Yao, L. H. Luthjens, A. Gasparini, and J.M. Warman, Radiation Physics and Chemistry 133, 37-44 (2017), https://doi.org/10.1016/j.radphyschem.2016.12.006.

[17] V.C. Borca, M. Pasquino, G. Russo, P. Grosso, D. Cante, P. Sciacero, G. Girelli, M.R.L. Porta, and S. Tofani, Journal of Applied Clinical Medical Physics, 14(2), 158-171 (2012), https://dx.doi.org/10.1120\%2Fjacmp.v14i2.4111.

[18] P. Andreo, D.T. Burns, K. Hohlfeld, M.S. Huq, T. Kanai, F. Laitano, V. Smyth, S. Vynckier, Absorbed Dose Determination In External Beam Radiotherapy: An International Code of Practice For Dosimetry Based On Standards Of Absorbed Dose To Water, International Atomic Energy Agency (IAEA), Technical Reports Series No. 398, IAEA TRS-398, (2006).

[19] A. Niroomand-Rad, C.R. Blackwell, B.M. Coursey, K.P. Gall, J.M. Galvin, W.L. McLaughlin, A.S. Meigooni, R. Nath, J.E. Rodgers, and C.G. Soares, Radiochromic film dosimetry: Recommendations of AAPM Radiation Therapy Committee Task Group 55 AAPM TG 55, (1998). 
[20] M. Mathot, S. Sobczak, and M.T. Hoornaert, Physica Medica, 30, 871-877 (2014), https://doi.org/10.1016/j.ejmp.2014.06.043.

[21] P. Sipila, J. Ojala, S. Kaijaluoto, I. Jokelainen, and A. Kosunen, Journal Of Applied Clinical Medical Physics, 17(1), 360-373 (2016), https://doi.org/10.1120/jacmp.v17i1.5970.

\section{ДОСЛІДЖЕННЯ РЕАКЦЇ̈ РАДІОХРОМНОЇ ПЛІВКИ ЕВТЗ \\ ПРИ ВИСОКИХ ДОЗАХ 6 МеВ ФОТОННИХ ТА 6 МеВ ЕЛЕКТРОННИХ ПУЧКІВ З ВИКОРИСТАННЯМ ТРИКОЛІРНОГО ПЛАНШЕТНОГО СКАНЕРА Керем Дуруер ${ }^{\mathbf{a} *}$, Дурмуш Етіз ${ }^{\mathrm{a}}$, Халук Юсель ${ }^{\mathrm{b}}$ \\ Університет Ескішехір Османгазі, медичний факультет, кафедра радіаційної онкології 26010, Одунпазарі, Эскішехір, Туриія \\ Інститут ядерних наук, Університет Анкари 06500, Бешевлер, Анкара, Туриія}

Радіохромна плівкова дозиметрія зазвичай використовується для визначення дози в радіотерапії протягом багатьох років через ii високого просторову здатність, низьку енергетичну залежність та приблизно тканино-еквівалентна. Крім того, плівкова дозиметрія має й інші практичні переваги, наприклад, підходить для променевих характеристик в терапевтичному діапазоні, водостійка, відносно нечутлива до видимого світла і не вимагає проведення водного процесу для отримання інформації про дозу. Плівки також не залежать від потужності дози. Отже, вони дуже корисні і практичні для клінічних застосувань, таких як брахітерапії, електронної терапія, виміру дози на шкірі і стереотаксичної радіотерапії. Серед іншого динамічний діапазон доз радіохромних плівок ЕВТ3 зазвичай рекомендується в діапазоні доз від 0,1 до 20 Гр. Однак в цьому дослідженні передбачається дослідження поведінки плівок ЕВТЗ при опроміненні в діапазоні високих доз до 90 Гр. 3 цією метою були отримані кінцеві оптичні щільності при збільшенні значень дози під пучками фотонів і електронів 3 використанням трьох кольорових каналів при скануванні (червоний-зелений-синій). Таким чином, для побудови калібрувальних кривих було вирішено, який колірний канал для радіохромної плівки ЕВТЗ буде найбільш відповідним до різних діапазонів доз. В експериментальній установці спочатку були встановлені еталонні умови, і процедура калібрування дози проводилася на фантомі RW3. Потім опромінені плівки були акуратно розрізані на шматочки розміром $2 \times 2,5 \mathrm{~cm}^{2}$ i згруповані в 2 групи - опромінення і контролю. Контрольні групи були фоновими, тобто вони не опромінювалися. Перед опроміненням дві групи плівок сканувалися в планшетному сканері для трьох каналів. Після цього плівки групи опромінення розміщали так, щоб вирівняти точне місце ефективної точки іонізаційної камери при стандартних умовах. Пізніше їх опромінювали по одному до 90 Гр з використанням променів $6 \mathrm{MeB}$ і $6 \mathrm{MeB}$ відповідно. Згодом обидві групи плівок були знову сканувались у трьох-колірному планшетному сканері. Зі сканованих плівок були отримані оптичні щільності і їх стандартні відхилення, які відповідають обраним значенням дози. Таким чином були побудовані калібрувальні криві для всіх трьох кольорових каналів відповідно до двох різних умов опромінення. Результати, отримані для променю $6 \mathrm{MeB,} \mathrm{показали,}$ що якщо канал червоного кольору обраний для діапазону дози 0,9 Гр-7,3 Гр, канал зеленого кольору обраний для діапазону дози 7,3 Гр-42,8 Гр, а канал синього кольору обраний для 42,8 Гр - 90,0 Гр, процентні значення невизначеності в отриманих результатах мінімальні. Для променю $6 \mathrm{MeB}$, якщо канал червоного кольору обраний для діапазону дози 0,9 Гр-7,7 Гр, і канал зеленого кольору обраний для діапазону дози 7,7 Гр-45,3 Гр, а канал синього кольору обраний для дози 45, 3 Гр-90,0 Гр, процентні значення невизначеності в отриманих результатах мінімальні. У підсумку, були оцінені значення невизначеності в процентах для отриманих результатів для енергій фотонів $6 \mathrm{MeB}$ і електронів $6 \mathrm{MeB}$ з використанням різних каналів сканування радіохромной плівки ЕВТ3. Було виявлено, що вимірювання, які мають низькі значення процентної невизначеності, можуть бути досягнуті зміною каналу сканування шляхом вибору правильних комбінацій зі збільшенням доз для обох енергій (фотонів $6 \mathrm{MeB}$ і електронів $6 \mathrm{MeB}$ ). Дослідження також показує, що радіохромні плівки ЕВТ3 можуть використовуватися при більш низьких значеннях процентної невизначеності при дозах, що перевищують рекомендовані значення діапазону доз.

КЛЮЧОВІ СЛОВА: радіохромна плівка, невизначеність, висока доза, радіотерапія, планшетний сканер.

\section{ИССЛЕДОВАНИЕ РЕАКЦИИ РАДИОХРОМИЧЕСКОЙ ПЛЕНКИ ЕВТЗ ПРИ ВЫСОКОЙ ДОЗЕ 6 МэВ ФОТОННЫХ И 6 МэВ ЭЛЕКТРОННЫХ ПУЧКОВ С ИСПОЛЬЗОВАНИЕМ ТРЕХЦВЕТНОГО ПЛОСКОГО СКАНЕРА Керем Дуруер ${ }^{\text {a,* }}$, Дурмуш Этиз ${ }^{\mathrm{a}}$, Халук Юсель \\ ${ }^{a}$ Университет Эскишехир Османгази, Медицинский факультет, Кафедра радиаџионной онкологии 26010, Одунпазари, Эскишехир, Туричи \\ ${ }^{b}$ Институт ядерных наук, Университет Анкары 06500, Бешевлер, Анкара, Туриия}

Радиохромная пленочная дозиметрия обычно используется для определения дозы в радиотерапии в течение многих лет из-за ее высокого пространственного разрешения, низкой энергетической зависимости и ее приблизительного тканевого эквивалента. Кроме того, она имеет и другие практические преимущества, например, подходит для лучевых характеристик в терапевтическом диапазоне, водостойкости, относительной нечувствительности к видимому свету и не требует проведения водного процесса для получения информации о дозе. Они также не зависят от мощности дозы. Следовательно, они очень полезны и практична для клинических применений, таких как брахитерапия, электронная терапия, измерение дозы на коже и стереотаксическая радиотерапия. Среди прочего динамический диапазон доз радиохромных пленок ЕВТЗ обычно рекомендуется в диапазоне доз от 0,1 до 20 Гр. Однако в этом исследовании предполагается исследование поведения пленок EBT3 при облучении в диапазоне высоких доз до 90 Гр. Для этой цели были получены конечные оптические плотности при увеличении значений дозы под пучками фотонов и электронов с использованием трех каналов цветного сканирования (красный-зеленый-синий). Таким образом, для построения калибровочных кривых было решено, какой цветовой канал для радиохромной пленки ЕВТ3 будет наиболее подходящим в различных диапазонах доз. В экспериментальной установке сначала были установлены эталонные условия, и процедура калибровки дозы проводилась в фантоме RW3. Затем облученные пленки были аккуратно разрезаны на кусочки размером $2 \times 2,5 \mathrm{~cm}^{2}$ и сгруппированы в 2 группы облучения и контроля. 
Контрольные группы являлись фоновыми, то есть они не облучались. Перед облучением две группы пленок сканировались в планшетном сканере для трех каналов. После этого пленки облучающей группы помещали так, чтобы выровнять точное место эффективной точки ионизационной камеры при стандартных условиях. Позднее их облучали по одному до 90 Гр с использованием лучей $6 \mathrm{MэВ} \mathrm{и} 6$ МэВ соответственно. Впоследствии обе группы пленок были снова отсканированы в планшетном сканере для трехцветных каналов. Из отсканированных пленок были получены оптические плотности и их стандартные отклонения, которые соответствующие выбранным значениям дозы. Таким образом были построены калибровочные кривые для всех трех цветов канала в соответствии с двумя различными условиями луча. Результаты, полученные для луча 6 МэВ, показали, что если канал красного цвета выбран для диапазона дозы 0,9 Гр-7,3 Гр, канал зеленого цвета выбран для диапазона дозы 7,3 Гр-42,8 Гр, а канал синего цвета выбран для 42,8 Гр - 90,0 Гр, процентные значения неопределенности в полученных результатах минимальны. Для луча 6 МэВ, если канал красного цвета выбран для диапазона дозы 0,9 Гр-7,7 Гр, и канал зеленого цвета выбран для диапазона дозы 7,7 Гр-45,3 Гр, а канал синего цвета выбран для дозы 45,3 Гр-90,0 Гр, процентные значения неопределенности в полученных результатах минимальны. В итоге, были оценены значения неопределенности в процентах для полученных результатов для энергий фотонов 6 МэВ и электронов 6 МэВ с использованием различных каналов сканирования радиохромной пленки ЕВТЗ. Было обнаружено, что измерения, имеющие низкие значения процентной неопределенности, могут быть достигнуты путем изменения канала сканирования путем выбора правильных комбинаций с увеличением доз для обеих энергий (фотон 6 МэВ и электрон 6 МэВ). Исследование также показывает, что радиохромные пленки ЕВТ3 могут использоваться при более низких значениях процентной неопределенности при дозах, превышающих рекомендуемые значения диапазона доз.

КЛЮЧЕВЫЕ СЛОВА: радиохромная пленка, неопределенность, высокая доза, радиотерапия, планшетный сканер. 